\title{
Valuable cancer registry
}

Munich

GERMAN reunification may bring an unexpected boon to the science of epidemiology in West Germany. Unlike West Germany, where strict laws to protect privacy have prevented the accumulation of national records on the incidence of cancer, East Germany has detailed records of all cancer cases since 1953.

West German doctors attending the 'first German medical congress' last month in Dresden spoke out for maintaining the East German registry and for trying to establish more cancer registries on a regional basis in West Germany. Georg Dhom, a pathologist in Homburg/ Saar, said that a senior health ministry official had indicated at a meeting last month that the federal government would consider establishing a 'national framework law' to allow the collection of data from cancer patients. Dhom is a member of a health ministry working group concerned with cancer epidemiology.

But as health policy is decided in West Germany by the Länder (states), the creation of a framework law could only be a first step. Such a law might encourage UNIFIED GERMANY

\section{Money, money, money}

\section{Munich}

ThE West German science council Wissenschaftsrat on 11 July called for massive aid for teaching and research in what is now East Germany in order to raise standards and make its universities more attractive to students and professors. At least DM6,500 million (about $\$ 4,000$ million) will be needed by 1995 , exclusive of running costs, said the council.

Good research and advanced study should be moved back from the East German Academy of Sciences to "diverse and properly functioning" East German universities, according to the council.

One way to do this, it suggested, is to remove from the academy the right of granting advanced degrees and teaching qualifications (Habilitation).

The council urged East German institutions and Western reviewers to resist the pressure simply to impose the West German system on East Germany. Instead, West Germany should take the opportunity to identify its own weaknesses and correct them.

The council also supported an increase of at least 25 per cent in the budgets of the Alexander von Humboldt Foundation and the German Academic Exchange Service (DAAD) to promote the international exchange of senior and junior researchers as well as students in a united Germany.

S.D. the establishment of regional cancer registries similar to those in Britain. West Germany has only two such registries now, in Saarland and in Hamburg.

Even though mandatory registration of cancer cases is forbidden by strict privacy laws in West Germany, Dhom said that the Saarland cancer registry has functioned well with voluntary participation by doctors. Doctors submit data together with the identification of cancer patients to the registry, which removes the names to protect the patients' privacy.

But he criticized as "expensive and technically difficult" the method chosen for a new registry in Baden-Württemberg. There, data are made anonymous before being reported to the central registry; Dohm predicted that double entries will become a major problem. The main reason this method was adopted, he said, was to please data protection activists who fear meddling by the state. But Dhom said that cancer patients in West Germany are in favour of more cancer registries and that opponents have succeeded in preventing their creation by using "very irrational" arguments.

Steven Dickman NAZI VICTIMS

\section{Graves desecrated}

\section{Munich}

UNKNOWN persons on 15 July desecrated the graves where body parts and tissue samples taken from the corpses of Nazi victims had been buried 11 days earlier. The samples had been in the collections of the University of Tübingen and were used for research and teaching purposes until a scandal in 1989 prompted their removal and eventual burial.

The criminals spray-painted swastikas onto the gravestones in the Tübingen city cemetery and hacked to pieces the stone that commemorated the victims.

The University of Tübingen held a commemorative ceremony on 8 July in honour of some 400 people whose remains were discovered in the collections of the Anatomy Institute. At the recommendation of an external committee, the university removed from the collections the remains of anyone who was known or even suspected to have been killed by the Nazi regime.

The destroyed stone was carved with a motto written by University of Tübingen pathologist Jürgen Peiffer: "Abducted, oppressed, violated,/Victims of despotism or blinded justice,/People did not find their rest until they arrived here./From their corpses even,/was demanded a service,/by a science that did not respect human values and dignity. /May this stone serve as a warning to the living."

S.D.

\section{Data released at last}

\section{Washington}

THE controversy over whether exposure to low-level radiation is linked to an increase in cancer deaths looks set to be refuelled after the US Department of Energy (DOE) last week finally released data on the radiation exposure and mortality rates of workers at nuclear weapons plants. The data are being released to the Three Mile Island Public Health Group which disputes the the official DOE opinion that low levels of radiation are safe because at worst they are linked only to one very rare form of cancer. DOE officials have until now been reticent to release their data, claiming that information on workers' health is confidential.

Success for TMI in a three-year lawsuit came only after pressure from Congress and the recommendation of a DOE panel of enquiry that public access be given to workers' health statistics.

This first installment of newly released data includes records of the radiation exposure and mortality rates of 44,000 people who worked at the DOE's Hanford Facility in Washington between the 1940s and 1981. Hanford is the DOE's oldest nuclear weapons manufacturing plant.

TMI will eventually have access to data on 200,000 workers, one-third of all of DOE 's personnel. But the terms of the legal agreement between TMI and DOE prevent TMI from releasing this information outside their research team.

With the new data, the 83-year-old TMI epidemiologist Alice Stewart hopes to update her earlier controversial studies with the Hanford population of workers. Her work was stopped in 1977 when her supervisor, Thomas Mancuso, lost his contract with DOE. That decision was in itself the subject of a congressional hearing.

Mancuso and his co-workers had published a study suggesting that increases in many kinds of common cancer could be seen at levels of radiation exposure that DOE considered safe.

Rival epidemiologists, including those under contract with the DOE and independent groups in British and Canada, dispute this finding. According to DOE contract researcher Ethel Gilbert of Battelle Pacific Northwest Laboratory, they have found only suggestions of a correlation between low-level radiation exposure and the ocurrence of multiple myeloma, a very rare cancer, in the DOE worker population. Data collected in Japan from studies of A-Bomb survivors do not support Stewart and Mancuso's conclusions.

DOE officials are currently considering how they will make data on all their workers available to the public. Robin Eisner 